\title{
Seasonal Variation and Removal of Organic Pollutants in Wastewater Using Low-Cost Treatment Technologies in Tamale Metropolis, Ghana
}

\author{
Felix K. Abagale \\ West African Centre for Water, Irrigation and Sustainable Agriculture, University for Development Studies, Tamale, Ghana \\ Email: fabagale@uds.edu.gh
}

How to cite this paper: Abagale, F.K. (2021) Seasonal Variation and Removal of Organic Pollutants in Wastewater Using Low-Cost Treatment Technologies in Tamale Metropolis, Ghana. Journal of Water Resource and Protection, 13, 271-282. https://doi.org/10.4236/jwarp.2021.134016

Received: January 9, 2021

Accepted: March 23, 2021

Published: March 26, 2021

Copyright ( 2021 by author(s) and Scientific Research Publishing Inc. This work is licensed under the Creative Commons Attribution International License (CC BY 4.0).

http://creativecommons.org/licenses/by/4.0/

(c) (i) Open Access

\begin{abstract}
The use of wastewater as alternative source of water for vegetable crop irrigation has become an eminent component of urban agriculture due to current global water crises in most developing countries, and admits the increasing effects of global climate change. The practise is however noted to be associated with significant health and environment risk due to excessive pollutant load. The study assessed the level of seasonal variation and removal of organic pollutants in wastewater using gravel filters combined with stabilisation ponds at Zagyuri in the Tamale Metropolis. The yard scale experiment consisted of cylindrical containers of different length filled with six different sizes of filter media and connected to stabilisation ponds where wastewater is allowed to pass through for filtration and stabilisation. The results indicated that for both seasons, the average concentration of BOD released into the stream at Zagyuri was $92.98 \mathrm{mg} / \mathrm{l}$ and $103.54 \mathrm{mg} / \mathrm{l}$ for the dry and wet season respectively whilst the COD was averaged $132.78 \mathrm{mg} / \mathrm{l}$ and $143.75 \mathrm{mg} / \mathrm{l}$ for the dry and wet seasons respectively. The results of the simple linear regression revealed a strong positive linear relationship between BOD and COD with coefficient of determination $\left(\mathrm{R}^{2}\right)$ of 0.873 which was statistically highly significantly at $\operatorname{Pr}$ value of $<0.0001$. The results for ANOVA for the treatment factor were statistically highly significant at $\operatorname{Pr}$ values of 0.0011 and $<0.0001$ respectively for $\mathrm{BOD}_{5}$ and $\mathrm{COD}$. The average concentration of $\mathrm{BOD}$ was higher than the Ghana EPA recommended levels while that of COD was lower and thus within safety range for discharge into the environment.
\end{abstract}

\section{Keywords}

Organic Pollutant, $\mathrm{BOD}_{5}, \mathrm{COD}$, Wastewater, Treatment 


\section{Introduction}

Despite the increasing effects of climate change coupled with intermittent water scarcity, alternative use of wastewater for vegetable crop irrigation has become an integral component of urban agriculture, especially in most developing countries where demand for all year-round vegetable production is eminent. According to McDonald et al. [1], over 150 million urban dwellers live with perennial water shortage. Global usage of untreated wastewater is estimated at 15 million $\mathrm{m}^{3} /$ day by over 200 million farmers and provides food of almost $10 \%$ of the global population [2]. Tamale metropolis located in the Guinea-savannah ecological zone, experiences a prolonged dry season due to the unimodal rainfall pattern and thus described as poorly endowed with waterbodies where the few seasonal streams completely dry up during the dry season [3]. The practise of wastewater irrigation thus remains the sole option for vegetable farmers to supplement the year-round water demand for vegetable production.

Despite the important contribution to food security, application of untreated wastewater however poses severe risk to public health and the environment due to excessive pollutant concentration and contaminant load. The raw wastewater usually from domestic or industrial sources is characterised by excessive organic pollution and usually found beyond allowable threshold for safe discharge or reuse. Kulabako et al., [4] mentioned that increase production of organic effluents due to rapid industrial growth poses severe environmental risk. Pollution of the limited water resources by the organic constitutes from the different sources of industrialization, agricultural activities and global environmental changes presents a major issue of concern due to the high toxicity levels and carcinogenic nature [5].

According to Sasse [6] reported that Chemical Oxygen Demand (COD) is a general parameter in measuring organic pollution and it describes how much oxygen is required in the oxidation of all organic and inorganic matter found in water. The author indicated that Biochemical Oxygen Demand (BOD) describes the fraction of COD that can be oxidised biologically by bacteria. According to Strauss et al. [7] in tropical countries, COD levels range from $500-2500 \mathrm{mg} / \mathrm{l}$ with a COD/BOD ratio of 2:1 in sewage. Kulabako et al. [4] and Sall et al. [8] mentioned that the strength of wastewater can be categorised as high strength based on its high COD concentration ( $>2 \mathrm{~g} / \mathrm{l})$.

Treatment of wastewater in aerobic ponds is possible with a $\mathrm{BOD}_{5}$ content below $300 \mathrm{mg} / \mathrm{l}$ and a limit of $50 \mathrm{mg} / \mathrm{l}$ must be taken before being discharged into the environment [6]. Tchobanoglous and Burton [9] and Güller et al. [2] indicated that the most widely used parameter of organic pollution for both wastewater and surface water is 5-day BOD. The universal application of $\mathrm{BOD}_{5}$ and COD for evaluation of organic pollutants and efficiency of wastewater treatment plants was also noted by Lee et al. [10]. Nonetheless reduction of organic pollution in wastewater by low-cost treatment technologies is critical in ensuring that levels are within safety limits for potential reuse, protection of the 
environment and public health. Simple technologies which operate with basic natural principles such as filtration and stabilisation are thus paramount. In this regard, filtration where wastewater is allowed to pass through a thick layer of sand is noted as a fundamental stage for water purification. The effect of filtration as noted for a significant removal of suspended and colloidal impurities, bacterial load and alteration of the chemical characteristics of wastewater, is principally based on the actions of mechanical straining, biological metabolism and sedimentation [11]. Waste Stabilisation pond is mentioned as the most important treatment method in developing countries where the temperature is most favourable for their operation [12]. They function as holding basins for secondary wastewater treatment where natural decomposition of organic matter occurs by complex symbiosis of bacteria and algae to a more stable and less offensive forms after a considerable retention time [13]. They are thus simple, low-cost and low-maintenance option for treating wastewater [14]. The study monitored the effect of seasonal variation on the concentration of the organic pollutants and as well tested the effect of gravel filters combined with pilot-scale stabilisation ponds as a low-cost treatment option for wastewater in the metropolis.

\section{Materials and Methods}

\subsection{Study Area}

The Tamale Metropolitan area is located at the centre of the Northern Region of Ghana. Tamale has been described as the fastest growing city in West Africa and it is the largest urban centre in the north of Ghana. It occupies $750 \mathrm{~km}^{2}$ which is $13 \%$ of the total area of the Northern Region. The population of Tamale Metropolis is reported as 371,351 [15]. The Metropolis experiences one rainy season starting from April/May to September/October with a peak period in July/August. The dry season is usually from November to March. The mean annual rainfall is $1100 \mathrm{~mm}$ within 95 days of intense rainfall. The mean day temperatures range from $33^{\circ} \mathrm{C}$ to $39^{\circ} \mathrm{C}$ while mean night temperature range from $20^{\circ} \mathrm{C}$ to $22^{\circ} \mathrm{C}$ and with the mean annual day sunshine is approximately 7.5 hours.

In the Metropolis there are several sites where wastewater vegetable farming takes place and the crops cultivated include cabbage, lettuce, Amaranthus, Chochorus and others. This study was done in the Zagyuri community of the Tamale Metropolis where community farmers numbering about 150 farmers and their families of averagely 5 members per household depend on the use of wastewater from a broken-down sewer of the Kamina Military Barracks for vegetable crop production. Figure 1 is a map of Ghana and the Tamale Metropolitan Area. The study area according to Obuobie et al. [16] is $8 \mathrm{~km}$ from the city centre and covers according to different sources in total about $7-12$ ha. The experimental field was located on latitude $09^{\circ} 47^{\prime} 388^{\prime \prime} \mathrm{N}$, longitude $00^{\circ} 84^{\prime} 776^{\prime \prime} \mathrm{W}$ and at an altitude of $167 \mathrm{~m}$ above sea level. 


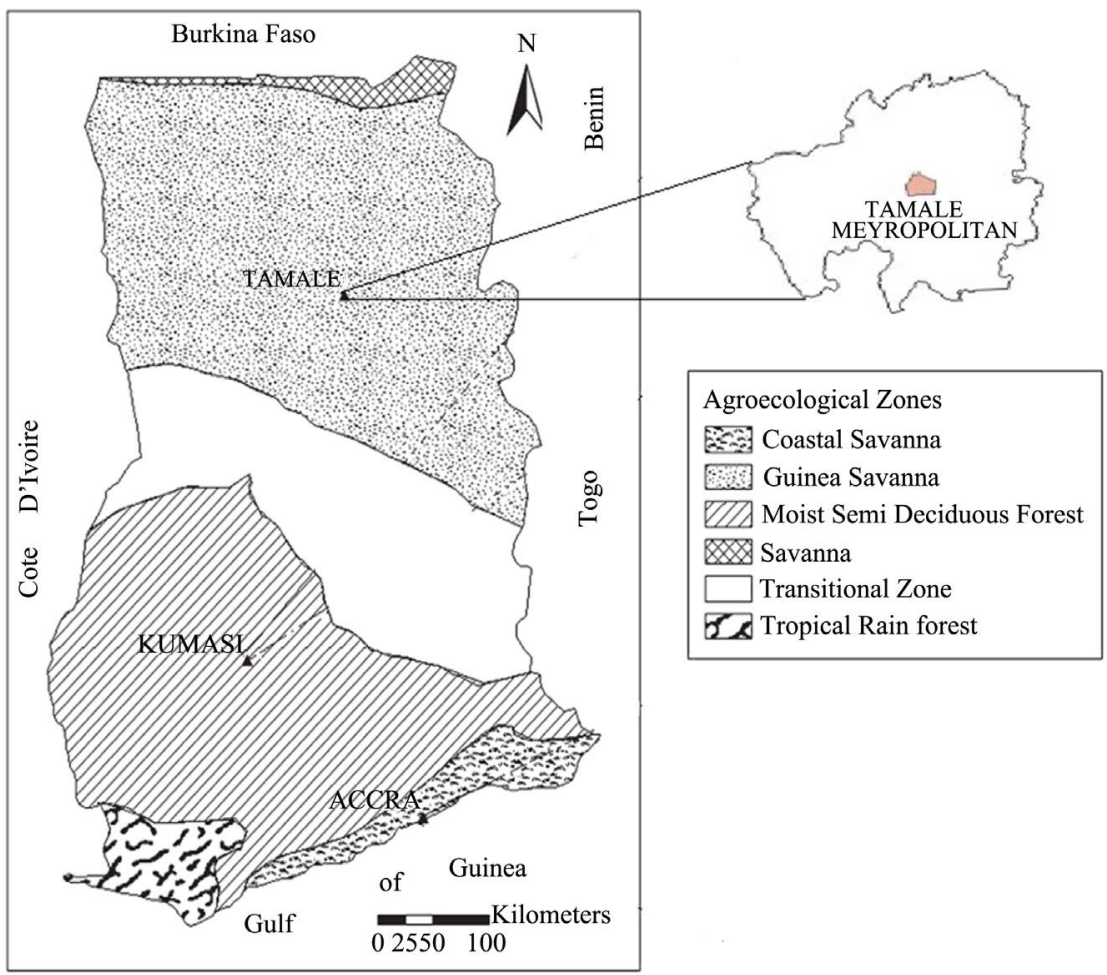

Figure 1. Map of Ghana showing the tamale metropolitan area, adopted from [17].

\subsection{Filter Unit and Experimental Designs}

The study designed and used eighteen cylindrical containers each with a diameter of $6.5 \mathrm{~cm}$ of varying lengths. Each horizontal sand filter unit was designed and fabricated to contain the following:

A mosquito netting at inflow and outflow ends to sieve out debris to prevent clogging.

The cylindrical shaped container set-up was made of one container only (8.5 $\mathrm{cm}$ length), two containers only (17 cm length) and three containers only (25.5 $\mathrm{cm}$ length) and serially connected to stabilization ponds.

Stabilization ponds were built at $2 \mathrm{~m} \times 7 \mathrm{~m}$ with a staircase design at $1 \mathrm{~m}$ interval for $2 \mathrm{~m}$ at intake point of the tank unit with the remaining $4.5 \mathrm{~m}$ being the depth of the stabilization pond.

Cement and concrete blocks were used for the construction of a staircase connecting the filter units to the stabilization ponds and the water source.

The experiment had three (3) treatments:

- Treatment one $\left(\mathrm{T}_{1}\right)$ where the length of the filtering container was $8.5 \mathrm{~cm}$,

- Treatment two $\left(\mathrm{T}_{2}\right)$ where the length of the filtering container was $17 \mathrm{~cm}$,

- Treatment three $\left(\mathrm{T}_{3}\right)$ where the length of the filtering container was $25.5 \mathrm{~cm}$, and

- The Control (Main Source, MS) where the wastewater was without any filtration.

The experimental layout was aided by the completely randomised design (CRD) where each treatment had three (3) replications (Figure 2). 


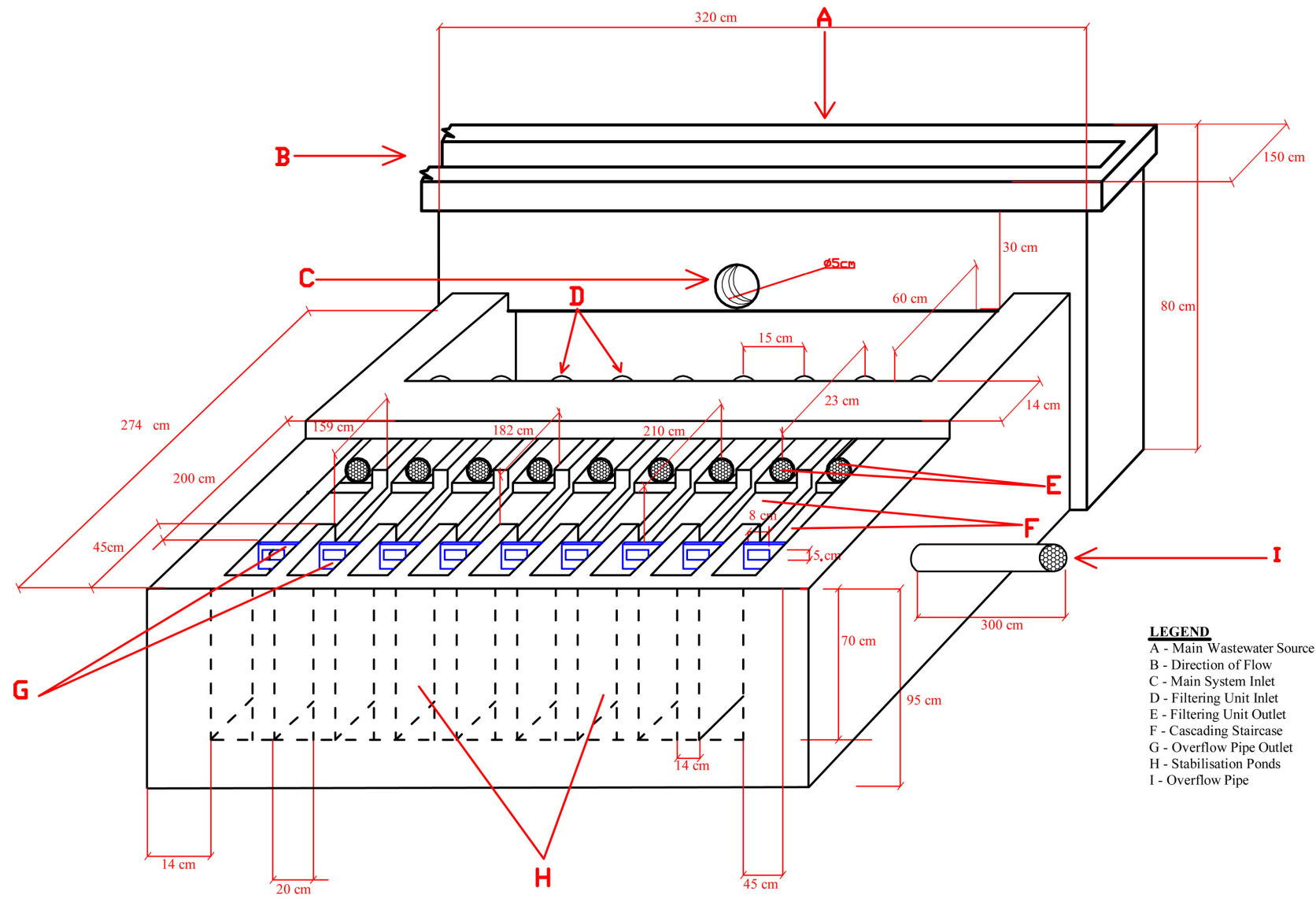

Figure 4.1: A SCHEMATIC DIAGRAM OF SAND FILTERING UNITS AND FARM STABILIZATION PONDS

Figure 2. A schematic diagram of on-farm sand filter units and farm stabilisation ponds.

Each filtering unit was filled with six (6) different sizes of the filter media as presented in Table 1. Stabilization ponds of dimensions $2 \mathrm{~m} \times 7 \mathrm{~m}$ were created to harvest the filtered wastewater from the various treatment set-ups. Wastewater from the Kamina Barracks sewage system was directed to the constructed treatment system. Wastewater samples were taken from each of the ponds and the main source to the laboratory for quality analysis. Three sampling repetitions at weekly intervals was analysed for eight weeks in both wet and dry seasons.

Concentration of COD was determined by the Close Reflux Dichromate Reduction Method while BOD was by Five days of incubation at $20^{\circ} \mathrm{C}$ with Oxytop head gas sensors in accordance with [18] Standard Methods for examination of wastewater and sludge.

\subsection{Data Analysis}

The average concentrations of the organic pollutants were subjected to trend analysis on weekly basis. Statistical significance for the variation among treatments and the sampling seasons were determined by Two-way Analysis of Variance (ANOVA) while relationship between the parameters was determined by Pearson's correlation at $5 \%$ level of significance. Separation of means was by 
Table 1. Filter media sizes.

\begin{tabular}{cc}
\hline Layer & Filter Media Size $(\mathrm{mm})$ \\
\hline Topmost & 2.00 \\
First & 4.75 \\
Second & 8.00 \\
Third & 19.0 \\
Fourth & 37.5 \\
Lowest & 45.0 \\
\hline
\end{tabular}

Tukey Pairwise Comparisons method. Relationship between average concentration of $\mathrm{BOD}_{5}$ and COD was determined by simple linear regression at $95 \%$ confidence interval whilst GraphPad Prism 8 was used for the data analysis and plotting of graphs.

\section{Results and Discussion}

\subsection{Variation of Biochemical Oxygen Demand $\left(\mathrm{BOD}_{5}\right)$ in Wastewater}

The level of $\mathrm{BOD}_{5}$ for the MS averaged $92.98 \mathrm{mg} / \mathrm{l}$ (Figure 3) (ranged from 55 to $159.1 \mathrm{mg} / \mathrm{l}$ ) for the dry season (Figure 3 ). The treatment effects were widely effective in the reduction of $\mathrm{BOD}_{5}$ to a minimum of $56.34 \mathrm{mg} / \mathrm{l}$ for $\mathrm{T}_{3}$ indicating that the activity of micro-organisms in the degradation of the organic component of the wastewater reduced greatly with increase in length of the filter column (Figure 4). As length of filter unit increased, micro-organisms which demand higher level of oxygen for oxidation of organic matter contained in the wastewater were filtered out. Micro-organisms concentration therefore corresponded well with the length of the filter unit. Weekly variation of $\mathrm{BOD}_{5}$ concentration in the dry season is presented in Figure 3(a).

In the wet season however, the concentration of the $\mathrm{BOD}_{5}$ for the MS averaged $103.54 \mathrm{mg} / \mathrm{l}$ (Figure 4) and ranged from 47.1 to $191.7 \mathrm{mg} / \mathrm{l}$ (Figure 3). The results indicate that the wet season was favourable for the activity of the micro-organisms responsible for the degradation of organic matter. It is therefore evident that the effect of environmental factors on the micro-organism's activity influenced the concentration of $\mathrm{BOD}$ in the wastewater. $\mathrm{BOD}_{5}$ concentration in the main source varied widely in the wet season and sometimes falling below the concentrations of the treatments. Dilution effect of rainwater could therefore be a contributory factor in the level of BOD concentration. Length of filter column was also realised to affect the BOD levels especially in week eight (Figure 3(b)). The environmental conditions together with filter length favoured the growth and activity of micro-organisms in the oxidation of organic matter contained in the wastewater. The results of ANOVA showed significant difference for variation among treatments at probability value (Pr value) of 0.0011 (Table 2), however the difference was realized for between the average concentration of MS and 


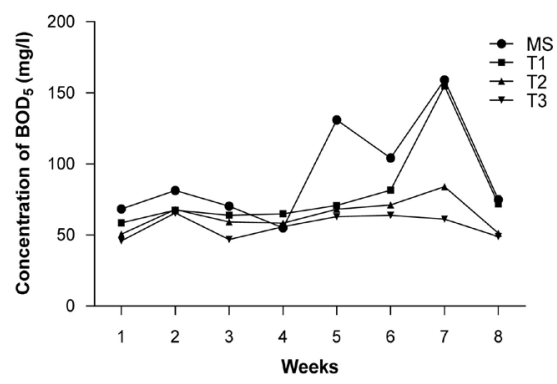

(a)

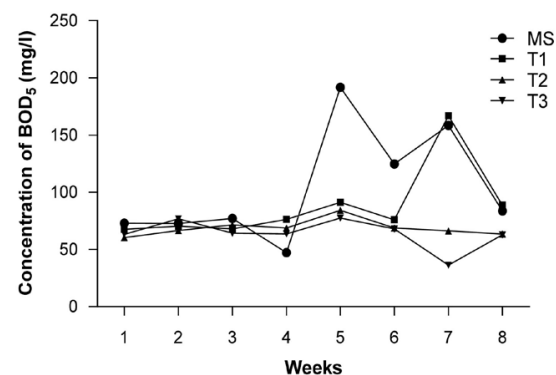

(b)

Figure 3. Weekly variation of $\mathrm{BOD}_{5}$. (a) Variation in the dry Season; (b) Variation in the wet season.

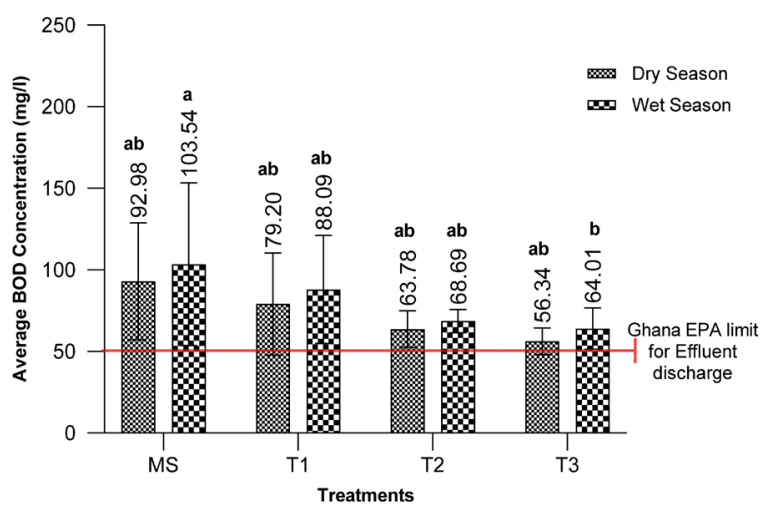

Means that do not share a letter are significantly different

Figure 4. Average $\mathrm{BOD}_{5}$ concentrations.

Table 2. ANOVA for concentration of $\mathrm{BOD}_{5}$.

\begin{tabular}{cccc}
\hline Source of Variation & \% of Total Variation & Pr Value & Pr Value Summary \\
\hline Interaction & 0.1149 & 0.9933 & $\mathrm{~ns}$ \\
Treatments & 24.22 & 0.0011 & $* *$ \\
Seasonal Variation & 1.736 & 0.2564 & $\mathrm{~ns}$ \\
\hline
\end{tabular}

Pr Value: Probability value; ${ }^{* *}$ level of significant difference; ns: no significant difference.

$\mathrm{T}_{3}$ of the dry season (Figure 4). According to L. Sasse [6], receiving waters should be able to tolerate effluent standards of between 30 to $70 \mathrm{mg} / \mathrm{l}$ BOD. Meanwhile the Ghana Environmental Protection Agency (EPA) allows for a maximum BOD discharge limit of $50 \mathrm{mg} / \mathrm{l}$ into the environment [19]. These higher values, however, indicate that the micro-organisms are active in the degradation process of the organic matter as low BOD was noted to indicate low level of the activity of biodegradable bacteria contained in the wastewater. Organic pollution of wastewater and surface water has been reported as the 5-day $\mathrm{BOD}\left(\mathrm{BOD}_{5}\right)[2][9][20]$.

\subsection{Variation of Chemical Oxygen Demand in Wastewater}

Chemical Oxygen Demand (COD) of the MS ranged from 105.15 to $205.90 \mathrm{mg} / \mathrm{l}$ 
for the dry season with an average COD of $132.78 \mathrm{mg} / \mathrm{l}$ (Figure 6).

Except in Week 7 when the COD concentration of $T_{1}$ was slightly higher than the main source, the COD of the various weeks of the main source was observed to be generally higher than the treatments (Figure 5(a)). Similar to $\mathrm{BOD}_{5}$, the length of filter unit was also observed to affect the level to which the COD was reduced to a minimum concentration of $76.63 \mathrm{mg} / \mathrm{l}$ for $\mathrm{T}_{3}$ in the dry season (Figure 6).

In the wet season, however, concentration of COD for MS ranged from 102.5 $\mathrm{mg} / \mathrm{l}$ to $203.00 \mathrm{mg} / \mathrm{l}$ (Figure 5(b)) with an average concentration of $143.75 \mathrm{mg} / \mathrm{l}$. Even though the limits were below that of the dry season, the average concentration of COD for the wet season was observed to be higher than that of the dry season (Figure 6). A similar trend of concentration of COD in the wet season like that of the dry season was observed.

Reduction of COD concentration in wastewater by the different treatment units was statistically highly significant at $\operatorname{Pr}$ value of $<0.000 .1$ (Table 3 ). The difference however was found between MS and all the treatments with the exception of $\mathrm{T}_{2}$ (Figure 6). Generally, this trend indicated that $\mathrm{T}_{3}$ was effective in reducing the level of COD contained in the wastewater. [6] noted that, for COD, the final effluent standards for discharge into receiving waters may tolerate from 100 to $200 \mathrm{mg} / \mathrm{l}$ while the Ghana EPA recommends a maximum discharge limit of $250 \mathrm{mg} / \mathrm{l}$ [19]. The average concentration of COD at the study area was thus within safe range for discharge.

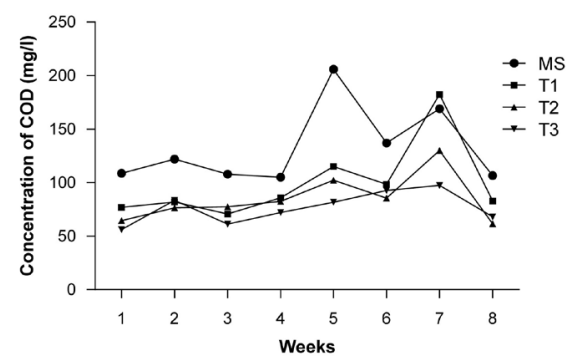

(a)

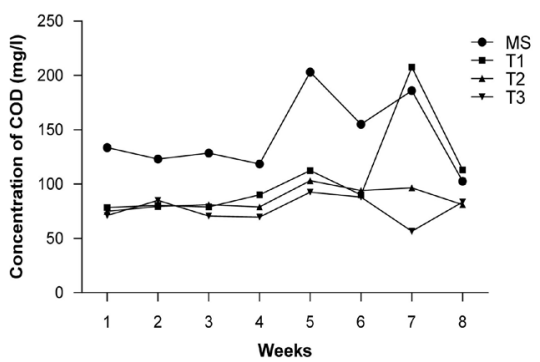

(b)

Figure 5. Weekly variation of COD. (a) Variation in the dry season; (b) Variation in the wet season.

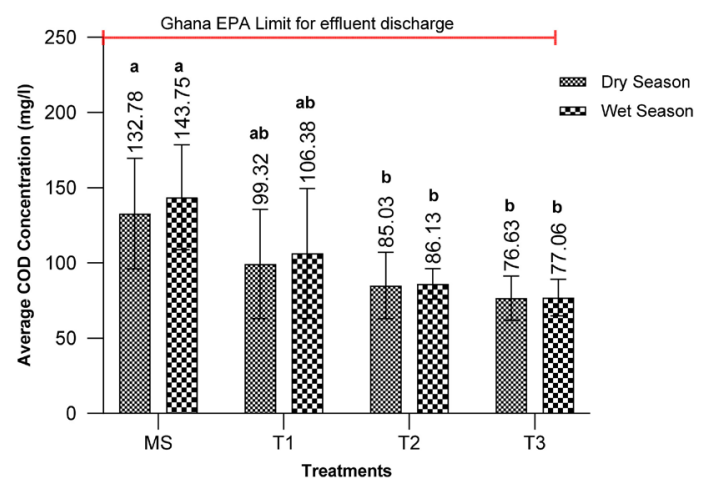

Figure 6. Average $\mathrm{BOD}_{5}$ concentrations. 


\subsection{Linear Relationship between BOD and COD}

The results of the simple linear regression revealed a strong positive linear relationship between BOD and COD with coefficient of determination $\left(\mathrm{R}^{2}\right)$ of 0.873 which was statistically highly significantly at $\operatorname{Pr}$ value of $<0.0001$ (Table 4 ). The results as presented in Figure 7 indicate that $81.73 \%$ of the variability of average BOD in the wastewater at the study area is influenced by the concentration of COD. The model equation for the relation was found to be $y=0.147+0.763 x$ with $\mathrm{x}$ and $\mathrm{y}$ representing $\mathrm{COD}$ and $\mathrm{BOD}_{5}$ respectively which implies that in the given range of the variable of COD in Table 4 a unit increase in COD will result to an increase of average BOD by 0.76 . A highly positive correlation coefficients between 0.81 to 0.93 was reported for brewery effluent in Ghana [20]. This implies that the concentration of BOD in wastewater effluent is significantly influence by that of the COD and thus treatment options should help reduce their levels to established threshold limits for safe discharge to avoid organic pollution in the environment and grantee potential reuse for agriculture.

\subsection{COD/BOD Ratio}

The COD/BOD ratio vaguely relates total oxidisable matter to organic matter which is first degraded by the most common bacteria [6]. The ratio between $\mathrm{COD}$ and $\mathrm{BOD}_{5}$ for the dry and wet seasons indicated that except for Week 4 of the wet season which recorded a $\mathrm{COD} / \mathrm{BOD}_{5}$ ratio of 2.52 , the remaining weeks were below a ratio of 2 (Table 5). Easily degradable wastewater has a COD/BOD 5

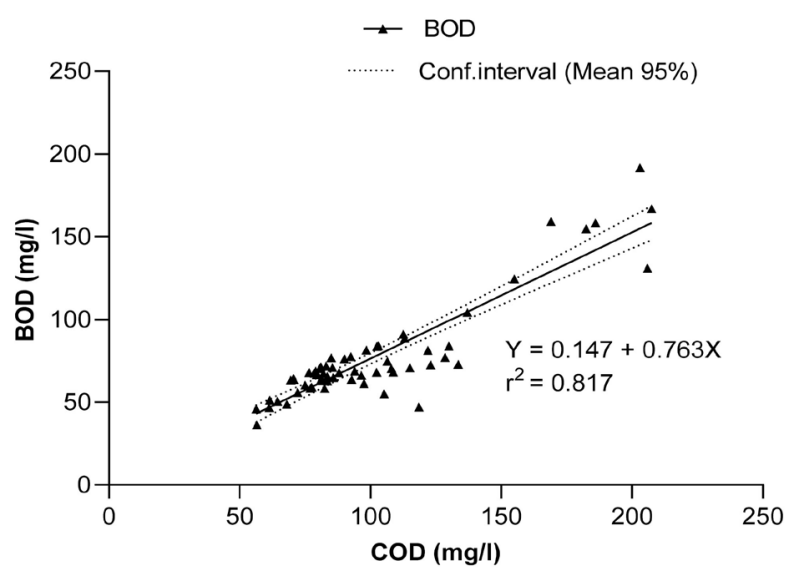

Figure 7. Relationship between $\mathrm{BOD}_{5} / \mathrm{COD}$ at the study area.

Table 3. ANOVA for concentration of COD.

\begin{tabular}{cccc}
\hline Source of Variation & \% of Total Variation & Pr Value & Pr Value Summary \\
\hline Interaction & 0.3662 & 0.9474 & $\mathrm{~ns}$ \\
Treatment & 42.64 & 0.0001 & $\star *$ \\
Seasonal Variation & 0.4606 & 0.5021 & $\mathrm{~ns}$ \\
\hline
\end{tabular}

Pr Value: Probability value; ${ }^{* *}$ level of significant difference; ns: no significant difference. 
Table 4. Model parameters for concentration of BOD.

\begin{tabular}{ccccccc}
\hline Source & \multicolumn{1}{c}{ Value } & Standard Error & $\mathbf{t}$ & $\operatorname{Pr}>|\mathbf{t}|$ & Lower Bound (95\%) & Upper Bound (95\%) \\
\hline Intercept & 0.147 & 4.917 & 0.030 & 0.976 & -9.682 & 9.975 \\
COD & 0.763 & 0.046 & 16.614 & $<0.0001$ & 0.671 & 0.854 \\
\hline
\end{tabular}

Table 5. Ratio of $\mathrm{COD} / \mathrm{BOD}_{5}$ of wastewater of the treatment units.

\begin{tabular}{ccccccccc}
\hline \multirow{2}{*}{ Week } & \multicolumn{4}{c}{ Dry Season } & \multicolumn{5}{c}{ Wet Season } \\
\cline { 2 - 9 } & MS & $\mathrm{T}_{1}$ & $\mathrm{~T}_{2}$ & $\mathrm{~T}_{3}$ & $\mathrm{MS}$ & $\mathrm{T}_{1}$ & $\mathrm{~T}_{2}$ & $\mathrm{~T}_{3}$ \\
\hline 1 & 1.59 & 1.31 & 1.27 & 1.23 & 1.83 & 1.16 & 1.24 & 1.12 \\
2 & 1.50 & 1.22 & 1.13 & 1.27 & 1.69 & 1.15 & 1.20 & 1.11 \\
3 & 1.53 & 1.11 & 1.31 & 1.31 & 1.67 & 1.16 & 1.13 & 1.10 \\
4 & 1.91 & 1.32 & 1.41 & 1.29 & 2.52 & 1.18 & 1.15 & 1.09 \\
5 & 1.57 & 1.63 & 1.50 & 1.30 & 1.06 & 1.23 & 1.22 & 1.19 \\
6 & 1.31 & 1.21 & 1.20 & 1.45 & 1.24 & 1.18 & 1.37 & 1.30 \\
7 & 1.06 & 1.18 & 1.55 & 1.59 & 1.17 & 1.24 & 1.46 & 1.56 \\
8 & 1.42 & 1.15 & 1.20 & 1.39 & 1.22 & 1.28 & 1.28 & 1.33 \\
\hline
\end{tabular}

relation of about 2. The COD/BOD ratio widens after biological treatment, because BOD is biologically degradable. A weak wastewater from domestic sources may have a COD below $500 \mathrm{mg} / \mathrm{l}$ while a strong industrial wastewater may contain up to $80,000 \mathrm{mg} / \mathrm{l} \mathrm{BOD} \mathrm{[6].} \mathrm{Andrio} \mathrm{et} \mathrm{al.} \mathrm{[21]} \mathrm{however} \mathrm{mentioned} \mathrm{the} \mathrm{case}$ of $\mathrm{BOD}_{5} / \mathrm{COD}$ as also an important relationship for understanding of biodegradability in wastewater and noted a minimum and optimal values of 0.4 and $<0.5$ respectively for easy biodegradability.

\section{Conclusions}

The results indicated that for both seasons, the average concentration of BOD released into the stream at Zagyuri was $92.98 \mathrm{mg} / \mathrm{l}$ and $103.54 \mathrm{mg} / \mathrm{l}$ for the dry and wet seasons respectively whilst the COD was averaged $132.78 \mathrm{mg} / \mathrm{l}$ and $143.75 \mathrm{mg} / \mathrm{l}$ for the dry and wet seasons respectively.

The treatment effects were widely effective in the reduction of both parameters as the degradation of the organic component of the wastewater reduced greatly with increase in length of the filter column. The treatment factor thus showed to be statistically significant for both parameters. The results of simple linear regression revealed a strong positive linear relationship between average concentration of BOD and COD which was statistically highly significantly at $P r$ value of $<0.0001$. The average concentration of BOD was higher than the Ghana EPA recommended levels while that of COD was lower and thus within safety range for discharge. The indication of the concentration means that the wet season was favourable for the activity of the micro-organisms responsible for the degradation of the organic matter. 


\section{Acknowledgements}

I would like to thank the following persons for supporting this work during the fieldwork and laboratory analysis of wastewater samples: Richard Osei Agyemang, Stephen Alenga, Patrick K. Antwi, and Emmanuel Nyadzi.

\section{Conflicts of Interest}

The author declares that the research was conducted in the absence of any commercial or financial relationships that could be construed as a potential conflict of interest.

\section{References}

[1] McDonald, R.I., Green, P., Balk, D., Fekete, B.M., Revenga, C., Todd, M. and Montgomery, M. (2011) Urban Growth, Climate Change and Freshwater Availability. Proceedings of the National Academy of Sciences, 108, 6312-6317. https://doi.org/10.1073/pnas.1011615108

[2] Güller, S., Silahtaroğlu, G. and Akpolat, O. (2019) Analysis Wastewater Characteristics via Data Mining: A Muğla Province Case and External Validation. Communications in Statistics: Case Studies, Data Analysis and Applications, 5, 200-213. https://doi.org/10.1080/23737484.2019.1604192

[3] Drechsel, P., Scott, C.A., Raschid-Sally, L., Redwood, M. and Bahri, A. (2010) Wastewater Irrigation and Health: Assessing and Mitigating Risk in Low-Income Countries. International Water Management Institute (IWMI), Colombo; Earthscan, London; International Development Research Centre (IDRC), Ottawa, 404 p.

[4] Kulabako, N.R., Ssonko, N.K.M. and Kinobe, J. (2011) Greywater Characteristics and Reuse in Tower Gardens in Peri-Urban Areas-Experiences of Kawaala, Kampala, Uganda. The Open Environmental Engineering Journal, 4, 147-154. https://doi.org/10.2174/1874829501104010147

[5] Ali, I., Asim, M. and Khan, T.A. (2012) Low-Cost Adsorbents for the Removal of Organic Pollutants from Wastewater. Journal of Environmental Management, 113, 170-183. https://doi.org/10.1016/j.jenvman.2012.08.028

[6] Sasse, L. (1998) Decentralised Wastewater Treatment in Developing Countries. A Publication of BORDA.

[7] Strauss, M., Larmie, S.A. and Heinss, U. (1997) Treatment of Sludges from On-Site Sanitation: Low-Cost Options. Water Science and Technology, 35, 129-136. https://doi.org/10.2166/wst.1997.0251

[8] Sall, O. and Takakashi, Y. (2006) Physical, Chemical and Biological Characteristics of Stored Grey Water from Unsewered Sun-Urban Dakar in Senegal. Urban Water Journal, 3, 153-164. https://doi.org/10.1080/15730620600961387

[9] Tchobanoglous, G. and Burton, F.L. (1995) Wastewater Engineering Treatment, Disposal and Reuse. 3rd Edition, Metcalf and Eddy Inc., New York.

[10] Lee, J., Lee, S., Yu, S. and Rhew, D. (2016) Relationships between Water Quality Parameters in Rivers and Lakes: $\mathrm{BOD}_{5}, \mathrm{COD}, \mathrm{NBOPs}$, and TOC. Environmental Monitoring and Assessment, 188, 252. https://doi.org/10.1007/s10661-016-5251-1

[11] Rangwala, S.C., Rangwala, K.S. and Rangwala, P.S. (2007) Water Supply and Sanitary Engineering. Charotar Publishing House, Anand, 200-201.

[12] Mara, D. (2004) Domestic Wastewater Treatment in Developing Countries. Earth- 
scan, London.

[13] Yvonne, L. (2012) Design of Sewage Treatment System for Gulu University. A Project Report, Gulu University, Gulu.

[14] Nelson, K.L., Cisneros, B.J., Tchobanoglous, G. and Darby, J.L. (2004) Sludge Accumulation, Characteristics and Pathogen Inactivation in Four Primary Waste Stabilization Ponds in Central Mexico. Water Research, 38, 111-127. https://doi.org/10.1016/j.watres.2003.09.013

[15] Ghana Statistical Service (2013) 2010 Population and Housing Census National Analytical Report.

[16] Obuobie, E., Keraita, B., Danso, G., Amoah, P., Cofie, O.O., Raschid-Sally, L. and Drechsel, P. (2006) Irrigated Urban Vegetable Production in Ghana: Characteristics, Benefits and Risks. IWMI-RUAF-CPWF, IWMI, Accra, 150 p.

[17] Abagale, F.K., Kyei-Baffour, N., Ofori, E. and Mensah, E. (2013) Types and Seasonal Diversity of Helminth Eggs in Wastewater Used for Peri-Urban Vegetable Crop Production in Tamale Metropolis, Ghana. International Journal of Current Research, 5, 3354-3359.

[18] APHA (2005) Standard Methods for the Examination of Water and Wastewater. 21st Edition, American Public Health Association, Washington DC.

[19] Owusu-Ansah, E.D.G.J., Sampson, A., Amponsah, S.K., Abaidoo, R.C. and Hald, T. (2015) Performance, Compliance and Reliability of Waste Stabilization Pond: Effluent Discharge Quality and Environmental Protection Agency Standards in Ghana.

[20] Attiogbe, F.K., Glover-Amengor, M. and Nyadziehe, K.T. (2007) Correlating Biochemical and Chemical Oxygen Demand of Effluents-A Case Study of Selected Industries in Kumasi, Ghana. West African Journal of Applied Ecology, 11, 155-164. https://doi.org/10.4314/wajae.v11i1.45722

[21] Andrio, D., Asmura, J., Yenie, E. and Putri, K. (2019) Enhancing BOD5/COD Ratio Co-Substrate Tofu Wastewater and Cow Dung during Ozone Pre-Treatment. MATEC Web of Conferences, 276, Article No. 06027. https://doi.org/10.1051/matecconf/201927606027 